\title{
Triterpenoids from Alisma orientale and their NF-kB Inhibitory Activity
}

\section{(ㄷ) (우) $\odot$}

\author{
Authors

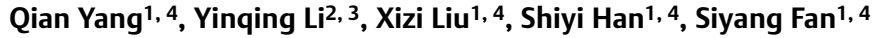

\section{Affiliations}

1 State Key Lab. of New Drug and Pharmaceutical Process, China State Institute of Pharmaceutical Industry, Shanghai, PR China

2 Shineway Pharmaceutical Group Ltd., Shijiazhuang, PR China

3 Hebei key Laboratory of Famous Classical Formulas and TCM Quality Process Control, Shijiazhuang, PR China

4 Innovation center of Traditional Chinese Medicine, Shanghai Institute of Pharmaceutical Industry, Shanghai, PR China

Key words

Alisma orientale, Alismataceae, triterpenoids, nuclear factor-kappa B

received 10.03 .2021

revised 23.06.2021

accepted 25.06.2021

\section{Bibliography}

Planta Med Int Open 2021; 8: e114-e121

DOI 10.1055/a-1543-1261

ISSN 2509-9264

(c) 2021. The Author(s).

This is an open access article published by Thieme under the terms of the Creative Commons Attribution-NonDerivative-NonCommercial-License, permitting copying and reproduction so long as the original work is given appropriate credit. Contents may not be used for commecial purposes, or adapted, remixed, transformed or built upon. (|s://creativecommons.org/ licenses/by-nc-nd/4.0/)

Georg Thieme Verlag KG, Rüdigerstraße 14,

70469 Stuttgart, Germany

\section{Correspondence}

Dr. Siyang Fan

State Key Lab. of New Drug and Pharmaceutical Process

China State Institute of Pharmaceutical Industry, Innovation center of Traditional Chinese Medicine, Shanghai Institute of Pharmaceutical Industry

285 Gebaini Road

Shanghai

P. R. China

Tel: + 86-21-20572000-2047, Fax: 02162474199

max_121@163.com

Supplementary Material is availale under

https://doi.org/10.1055/a-1543-1261.

\begin{abstract}
The rhizome of Alisma orientale (sam.) Juz. is used in clinics for eliminating dampness, reducing edema, and promoting diuresis. This study aimed to elucidate the compounds and investigate their nuclear factor-kappa inhibitory activities in human embryonic kidney 293 cells. A new triterpene, alismaketone B (1); a new natural nortriterpene, noralisolic acid A (2); and 13 known protostane-type triterpenes were isolated from the rhizome of $A$. orientale. The new structures and their absolute configurations were established using HRESIMS, NMR, and electronic circular dichroism experiments. All isolated compounds were evaluated for their inhibitory activity on NF-KB.

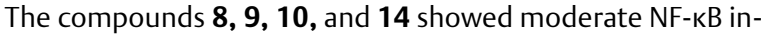
hibitory activities with their $\mathrm{IC}_{50}$ values being $64.7,32.3,47.3$, and $37.3 \mu \mathrm{M}$, respectively.
\end{abstract}

$\begin{array}{ll}\text { ABBREVIATIONS } \\ \text { TCM } & \text { traditional Chinese medicine } \\ \text { NF- } \mathrm{KB} & \text { nuclear factor-kappa B } \\ \text { ECD } & \text { electronic circular dichroism } \\ \text { TDDFT } & \text { time-dependent density functional theory } \\ \text { CC } & \text { column chromatography }\end{array}$

\section{Introduction}

Alisma orientale (Sam.) Juz. (Alismataceae) is an aquatic medicinal herb mainly harvested in Fujian, Jiangxi, and Sichuan, China. This plant's dried tubers (Rhizoma alismatis), known as "Zexie" in China [1], are often used in clinics for eliminating dampness, reducing edema, and promoting diuresis [2, 3]. Triterpenes [4, 5] and sesquiterpenes [6] are the major components in $A$. orientale tubes. Pharmacological studies showed that this plant's ethanol or water extracts have diuretic [7], lipid-lowering [8], liver-protecting [9], 
hypoglycemic [10], anti-inflammatory [11], and renal protective activities [12]. Besides, $A$. orientale's ethanol extract attenuates lung inflammation in LPS-induced acute lung injury mice by suppressing NF-KB and nuclear factor erythroid-2 related factor 2 activities $[13,14]$. However, the $A$. orientale's triterpenoids' inhibitory activities on NF-KB are still to be studied.

In this study, 15 protostane-type triterpenoids (1-15), including a new triterpenoid, alismaketone $B(\mathbf{1})$, and a new natural nortriterpene, noralisolic acid A (2), as well as a known fatty acid compound (16), were identified from A. orientale's rhizomes ( $\triangleright$ Fig. 1). The new compounds' absolute structures were elucidated by various spectroscopic or spectrometric methods, including 1D and 2D NMR, HRESIMS, and ECD. HEK293/NF-KB cells were used to investigate the 15 triterpenoids' NF-кB inhibition potential, and the isolates' $I C_{50}$ values were evaluated for their activities. These compounds exhibited NF-KB inhibition properties and could explain the plant's traditional use to treat renal diseases.

\section{Results and Discussion}

The rhizomes of $A$. orientale were extracted with $60 \% \mathrm{EtOH}$ to produce a brown crude extract. The extract was separated using silica gel and ODS-A column chromatography as well as semi-preparative HPLC into a new triterpenoid (1), alismaketone B; a new natural nortriterpene, noralisolic acid A (2); and 14 known compounds (3-16). Compound identification was performed using mass spectrometry and NMR spectroscopy, and spectroscopic data were compared with reference compounds reported in the literature. The known compounds were identified as follows: alisol C 23-acetate (3) [15], alisol Q 23-acetate (4) [15], 16,23-oxido-alisol B (5) [16], alismalactone 23-acetate (6) [17], alisol A (7) [15], 25-Omethylalisol A (8) [18], alisol B (9) [15], 25-O-ethylalisol A (10) [18], alisol C (11) [16], alisol $F(12)$ [19], 16-oxo-11-deoxy-alisol A (13) [16], alisol A 24-acetate (14) [15], 16-oxoalisol A (15) [16], and (9Z,12Z)-2,3-dihydroxypropyl octadecadienoate (16) [20].

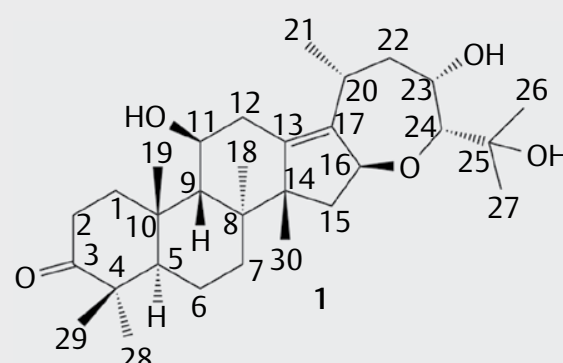

28

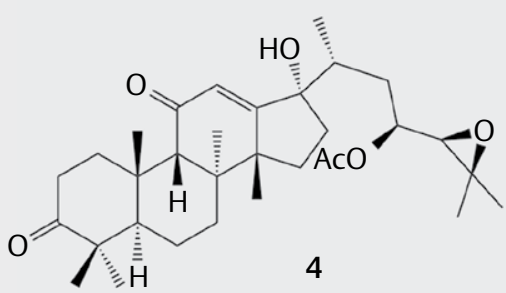<smiles>CC1(C)CCCC(=O)C1(C)C</smiles>

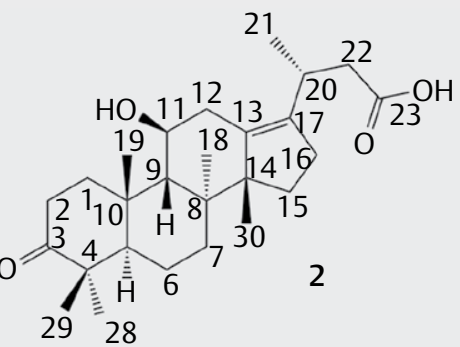

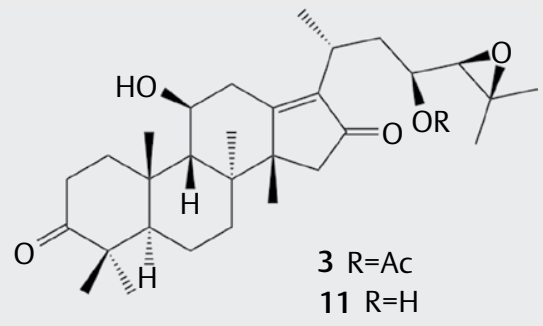

$11 \mathrm{R}=\mathrm{H}$

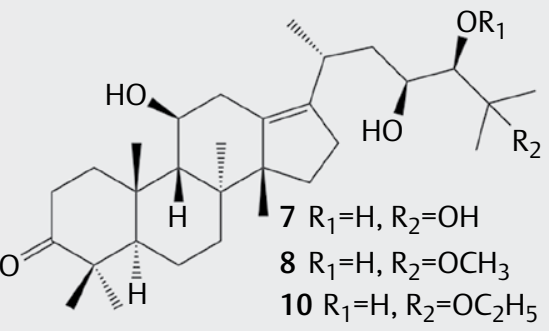

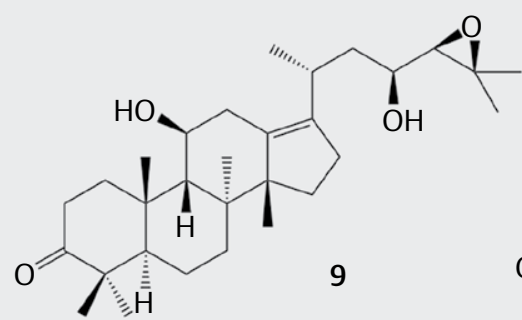

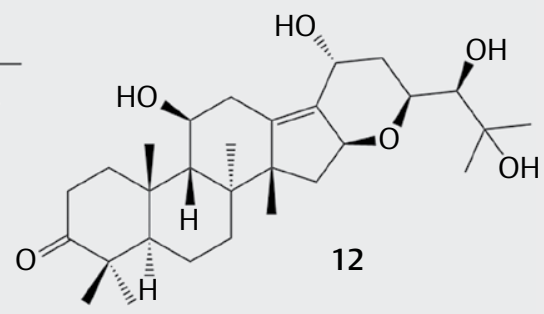

$14 \mathrm{R}_{1}=\mathrm{Ac}, \mathrm{R}_{2}=\mathrm{OH}$

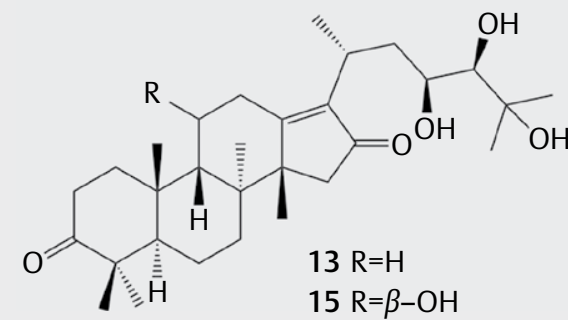<smiles>CC(=O)OCC(O)CO</smiles><smiles>C/C=C\C/C=C\C</smiles>
$\left(\mathrm{CH}_{2}\right)_{4}$

- Fig. 1 Compounds isolated from A. orientale. 
Compound 1 was obtained as a yellow amorphous powder. This compound's molecular formula was established as $\mathrm{C}_{30} \mathrm{H}_{48} \mathrm{O}_{5}$ with a positive HRESIMS ( $\mathrm{m} / \mathrm{z}$ 533.3499, calcd. 533.3478, [M+ $\mathrm{HCOO}]^{-}$). The ${ }^{1} \mathrm{H}$ NMR spectrum ( Table $\mathbf{1}$ ) of $\mathbf{1}$ showed the presence of 8 methyl groups at $\delta_{\mathrm{H}} 1.32(\mathrm{~s}), 1.27(\mathrm{~s}), 1.19(\mathrm{~s}), 1.17(\mathrm{~d}, J=7.1 \mathrm{~Hz})$, $1.07(\mathrm{~s}), 1.06(\mathrm{~s}), 1.05(\mathrm{~s})$, and $0.89(\mathrm{~s})$ and 4 oxygenated methines at $\delta_{H} 5.13(\mathrm{t}, J=6.5 \mathrm{~Hz}), 4.10(\mathrm{~m}), 3.28(\mathrm{~m})$, and $3.83(\mathrm{~m})$. The ${ }^{13} \mathrm{C}$ NMR spectrum displayed 30 signals, including a carbonyl carbon at $\delta_{\mathrm{C}} 220.0 ; 2$ olefinic carbons at $\delta_{\mathrm{C}} 142.6$ and $135.5 ; 4$ oxygenated methine carbons at $\delta_{C} 69.9,71.7,76.6$, and 83.6; and an oxygen-

> Table $1{ }^{1} \mathrm{H}(400 \mathrm{MHz})$ and ${ }^{13} \mathrm{C}(100 \mathrm{MHz})$ NMR for compounds 1 and 2 in $\mathrm{CDCl}_{3}$.

\begin{tabular}{|c|c|c|c|c|}
\hline \multirow[t]{2}{*}{ Pos. } & \multicolumn{2}{|c|}{1} & \multicolumn{2}{|c|}{2} \\
\hline & $\delta_{\mathrm{H}}, J(\mathrm{~Hz})$ & $\delta_{\mathrm{c}}$ & $\delta_{\mathrm{H}}, J(\mathrm{~Hz})$ & $\delta_{\mathrm{C}}$ \\
\hline \multirow[t]{2}{*}{1} & $2.20 \mathrm{~m}$ & \multirow{2}{*}{$30.7(\mathrm{t})$} & $2.23 \mathrm{~m}$ & \multirow[t]{2}{*}{$31.0(\mathrm{t})$} \\
\hline & $2.06 \mathrm{~m}$ & & $2.10 \mathrm{~m}$ & \\
\hline \multirow[t]{2}{*}{2} & $2.67 \mathrm{~m}$ & \multirow[t]{2}{*}{$33.5(\mathrm{t})$} & $2.66 \mathrm{~m}$ & \multirow[t]{2}{*}{$33.7(\mathrm{t})$} \\
\hline & $2.34 \mathrm{~m}$ & & $2.33 \mathrm{~m}$ & \\
\hline 3 & - & $220.0(s)$ & - & $220.4(\mathrm{~s})$ \\
\hline 4 & - & $46.9(\mathrm{~s})$ & - & $47.0(\mathrm{~s})$ \\
\hline 5 & $2.11 \mathrm{~m}$ & 48.2 (d) & $2.08 \mathrm{~m}$ & 48.5 (d) \\
\hline \multirow[t]{2}{*}{6} & $1.47 \mathrm{~m}$ & \multirow[t]{2}{*}{$19.9(\mathrm{t})$} & $1.45 \mathrm{~m}$ & \multirow[t]{2}{*}{$20.0(\mathrm{t})$} \\
\hline & $1.28 \mathrm{~m}$ & & $1.29 \mathrm{~m}$ & \\
\hline \multirow[t]{2}{*}{7} & $2.02 \mathrm{~m}$ & \multirow[t]{2}{*}{$34.4(\mathrm{t})$} & $2.70 \mathrm{~m}$ & \multirow[t]{2}{*}{$34.3(\mathrm{t})$} \\
\hline & $1.28 \mathrm{~m}$ & & $1.23 \mathrm{~m}$ & \\
\hline 8 & - & $40.6(s)$ & - & $40.5(s)$ \\
\hline 9 & $1.75 \mathrm{~d}(10.7)$ & 49.3 (d) & $1.72 \mathrm{~d}(10.6)$ & 49.6 (d) \\
\hline 10 & - & $36.9(\mathrm{~s})$ & - & $36.9(\mathrm{~s})$ \\
\hline 11 & $3.83 \mathrm{~m}$ & 69.9 (d) & $3.85 \mathrm{~m}$ & $70.0(\mathrm{~d})$ \\
\hline \multirow[t]{2}{*}{12} & $2.64 \mathrm{~m}$ & \multirow[t]{2}{*}{$34.1(\mathrm{t})$} & $2.76 \mathrm{~m}$ & \multirow[t]{2}{*}{$34.4(\mathrm{t})$} \\
\hline & $2.08 \mathrm{~m}$ & & $2.02 \mathrm{~m}$ & \\
\hline 13 & - & $142.6(\mathrm{~s})$ & - & $137.3(\mathrm{~s})$ \\
\hline 14 & - & $54.8(\mathrm{~s})$ & - & $57.0(\mathrm{~s})$ \\
\hline \multirow[t]{2}{*}{15} & $2.32 \mathrm{~m}$ & \multirow[t]{2}{*}{$40.0(\mathrm{t})$} & $1.87 \mathrm{~m}$ & \multirow[t]{2}{*}{$30.5(\mathrm{t})$} \\
\hline & $1.33 \mathrm{~m}$ & & $1.34 \mathrm{~m}$ & \\
\hline \multirow[t]{2}{*}{16} & \multirow[t]{2}{*}{$5.13 \mathrm{t}(6.5)$} & \multirow[t]{2}{*}{83.8 (d) } & $2.29 \mathrm{~m}$ & \multirow[t]{2}{*}{$29.3(\mathrm{t})$} \\
\hline & & & $2.17 \mathrm{~m}$ & \\
\hline 17 & - & $135.6(\mathrm{~s})$ & - & $134.5(\mathrm{~s})$ \\
\hline 18 & $1.19 \mathrm{~s}$ & $23.6(q)$ & $0.97 \mathrm{~s}$ & $24.1(q)$ \\
\hline 19 & $1.06 \mathrm{~s}$ & $25.4(q)$ & $1.05 \mathrm{~s}$ & $25.6(q)$ \\
\hline 20 & $2.69 \mathrm{~m}$ & 28.7 (d) & $3.07 \mathrm{~m}$ & 29.4 (d) \\
\hline 21 & $1.17 \mathrm{~d}(7.1)$ & $20.8(q)$ & $1.06 \mathrm{~d}(7.1)$ & 19.5 (q) \\
\hline \multirow[t]{2}{*}{22} & $1.88 \mathrm{~m}$ & \multirow[t]{2}{*}{$41.2(\mathrm{t})$} & $2.31 \mathrm{~m}$ & $40.0(\mathrm{t})$ \\
\hline & $1.70 \mathrm{~m}$ & & & \\
\hline 23 & $4.10 \mathrm{~m}$ & 71.7 (d) & - & $177.0(\mathrm{~s})$ \\
\hline 24 & $3.28 \mathrm{~m}$ & $76.6(d)$ & - & - \\
\hline 25 & - & $73.7(\mathrm{~s})$ & - & - \\
\hline 26 & $1.32 \mathrm{~s}$ & $26.1(q)$ & - & - \\
\hline 27 & $1.27 \mathrm{~s}$ & $28.6(q)$ & - & - \\
\hline 28 & $1.07 \mathrm{~s}$ & $29.5(q)$ & $1.07 \mathrm{~s}$ & $29.6(q)$ \\
\hline 29 & $1.05 \mathrm{~s}$ & $20.0(q)$ & $1.05 \mathrm{~s}$ & 20.1 (q) \\
\hline 30 & $0.89 \mathrm{~s}$ & $23.5(q)$ & $1.10 \mathrm{~s}$ & $22.8(q)$ \\
\hline
\end{tabular}

ated quaternary carbon at $\delta_{\mathrm{C}}$ 73.7. Furthermore, 4 quaternary carbons, 3 methines, 7 methylenes, and 8 methyls were determined using ${ }^{13} \mathrm{C}$ NMR and DEPT experiments. These data closely resembled those of alismaketones B 23-acetate [21], except for the absence of an acetyl group at C-23. Accordingly, compound $\mathbf{1}$ should have a hydroxyl group at C-23 instead of the 23-acetate of alismaketones $\mathrm{B} 23$-acetate. The structure of compound 1 was confirmed by the correlations of $\mathrm{H}-26\left(\delta_{\mathrm{H}} 1.32\right) / \mathrm{C}-27\left(\delta_{\mathrm{C}} 28.6\right), \mathrm{H}-24\left(\delta_{\mathrm{H}} 3.28\right) /$ $\mathrm{C}-27\left(\delta_{\mathrm{C}} 28.6\right), \mathrm{H}-23\left(\delta_{\mathrm{H}} 4.10\right) / \mathrm{C}-20\left(\delta_{\mathrm{C}} 28.7\right), \mathrm{H}-21\left(\delta_{\mathrm{H}} 1.17\right) / \mathrm{C}-22\left(\delta_{\mathrm{C}}\right.$ 41.2), and $\mathrm{H}-16\left(\delta_{\mathrm{H}} 5.13\right) / \mathrm{C}-24\left(\delta_{\mathrm{C}} 76.6\right)$ observed in the HMBC spectrum, which we have shown in $>$ Fig. 2.

The relative configuration of compound $\mathbf{1}$ was established from the $3 \int_{H, H}$ coupling value as well as NOESY data. A considerable $3 / 9,11$ value of $10.7 \mathrm{~Hz}$ indicated the axial-axial relationship of $\mathrm{H}-9$ and $\mathrm{H}$-11. As shown in $>$ Fig. 2, the NOESY correlations of Me-18 $\left(\delta_{\mathrm{H}}\right.$ $0.89)$ with $\mathrm{H}-5\left(\delta_{\mathrm{H}} 2.11\right), \mathrm{H}-11\left(\delta_{\mathrm{H}} 3.83\right), \mathrm{H}-16\left(\delta_{\mathrm{H}} 5.13\right)$, and $\mathrm{H}-15 \alpha$ $\left(\delta_{\mathrm{H}} 2.32\right)$; the correlations of Me-30 $\left(\delta_{\mathrm{H}} 1.19\right)$ with $\mathrm{H}-9\left(\delta_{\mathrm{H}} 1.75\right)$ and $\mathrm{H}-24\left(\delta_{\mathrm{H}} 3.28\right)$; and the correlation of $\mathrm{H}-24\left(\delta_{\mathrm{H}} 3.28\right)$ with $\mathrm{H}-15 \beta\left(\delta_{\mathrm{H}} 1.33\right)$ indicated that $\mathrm{H}-5, \mathrm{H}-11, \mathrm{H}-16$, and Me-18 were $\alpha$-oriented, whereas $\mathrm{H}-9, \mathrm{H}-24$, and Me-30 were $\beta$-oriented. Additionally, the correlations of Me-19 $\left(\delta_{\mathrm{H}} 1.06\right) / \mathrm{H}-9\left(\delta_{\mathrm{H}} 1.75\right), \mathrm{H}-20\left(\delta_{\mathrm{H}}\right.$ $2.70) / \mathrm{H}-23\left(\delta_{\mathrm{H}} 4.10\right), \mathrm{H}-11\left(\delta_{\mathrm{H}} 3.83\right) / \mathrm{Me}-21\left(\delta_{\mathrm{H}} 1.17\right)$, and $\mathrm{H}-16\left(\delta_{\mathrm{H}}\right.$ $5.13) / \mathrm{Me}-21\left(\delta_{\mathrm{H}} 1.17\right)$ indicated the $\beta$-configurations of Me-19, $\mathrm{H}-20$, and $\mathrm{H}-23$. Compound 1's experimental ECD spectrum showed a positive cotton effect at $290 \mathrm{~nm}$ and a negative cotton effect at $205 \mathrm{~nm}$. The comparison between the TDDFT calculated spectrum (B3LYP/6-311 G * level) and the experimental data showed good agreement with $5 R, 8 R, 9 S, 10 S, 11 S, 14 S, 15 S, 20 R$, $23 S$, and $24 R$. Still, the alternative form revealed a curve with the opposite cotton effect ( $\vee$ Fig. 3 ). To the best of our knowledge, 1 was designated as the new protostane-type triterpenoid alismaketone $\mathrm{B}$.

Compound 2 was obtained as a yellow amorphous powder. This compound's molecular formula was assigned as $\mathrm{C}_{26} \mathrm{H}_{40} \mathrm{O}_{4}$ by negative HRESIMS at $\mathrm{m} / \mathrm{z} 461.2883$ [M + $\mathrm{HCOO}^{-}$(calcd. 461.2903). The ${ }^{1} \mathrm{H}$-NMR spectrum ( $\triangleright$ Table 1 ) showed 6 tertiary methyl groups at $\delta_{\mathrm{H}} 0.97(\mathrm{~s}), 1.05(\mathrm{~s}), 1.05(\mathrm{~s}), 1.06(\mathrm{~d}, J=7.1 \mathrm{~Hz}), 1.07(\mathrm{~s})$, and $1.10(\mathrm{~s})$ and an oxygenated proton signal at $\delta_{\mathrm{H}} 3.85(1 \mathrm{H}, \mathrm{m})$. The ${ }^{13} \mathrm{C}$-NMR data displayed signals for 2 carbonyls at $\delta_{\mathrm{C}} 220.4$ and 177.0. Compound 2's ${ }^{1} \mathrm{H}$ and ${ }^{13} \mathrm{C}$ NMR spectroscopic data were highly similar to those reported for alisol A (7) [15], except for the absence of oxygenated carbon signals at C-23, C-24, and C-25, and the presence of an additional carbonyl group $\left(\delta_{C} 177.0\right)$. Accordingly, $\mathbf{2}$ should have a carboxyl group at C-23 instead of the triol unit of alisol $\mathrm{A}(7)$. This feature is consistent with $\mathrm{HMBC}$ correlations observed ( Fig. 4) between $\mathrm{H}-22\left(\delta_{\mathrm{H}} 2.31\right)$ and $\mathrm{C}-23\left(\delta_{\mathrm{C}} 177.0\right)$, $\mathrm{C}-21\left(\delta_{\mathrm{C}} 40.0\right)$ and $\mathrm{C}-17\left(\delta_{\mathrm{C}} 134.5\right), \mathrm{H}-20\left(\delta_{\mathrm{H}} 3.07\right)$ and $\mathrm{C}-23\left(\delta_{\mathrm{C}}\right.$ $177.0)$, as well as between $\mathrm{H}-20\left(\delta_{\mathrm{H}} 3.07\right)$ and $\mathrm{C}-16\left(\delta_{\mathrm{C}} 29.3\right)$.

A considerable $3 \int_{9,11}$ value of $10.6 \mathrm{~Hz}$ indicated the axial-axial relationship of $\mathrm{H}-9$ and $\mathrm{H}-11$. The NOESY correlations of Me-18 $\left(\delta_{\mathrm{H}}\right.$ $0.97) / \mathrm{H}-11\left(\delta_{\mathrm{H}} 3.85\right), \mathrm{H}-11 / \mathrm{H}-5\left(\delta_{\mathrm{H}} 2.08\right), \mathrm{Me}-18 / \mathrm{H}-15 \alpha\left(\delta_{\mathrm{H}} 1.87\right)$, Me-30 $\left(\delta_{\mathrm{H}} 1.10\right) / \mathrm{H}-9\left(\delta_{\mathrm{H}} 1.72\right)$, Me-30/H-15ß $\left(\delta_{\mathrm{H}} 1.34\right)$, and $\mathrm{H}-9 /$ Me-19 $\left(\delta_{H} 1.05\right)$ supported the chair, boat, and chair conformations of rings $A, B$, and $C$, as well as their ring junction's trans-cis-trans relationships ( $\mathbf{F i g}$. 4). The experimental ECD spectrum of $\mathbf{2}$ showed a positive cotton effect at $293 \mathrm{~nm}$ and a negative cotton effect at $203 \mathrm{~nm}$. A comparison of the TDDFT-calculated spectrum (B3LYP/6- 


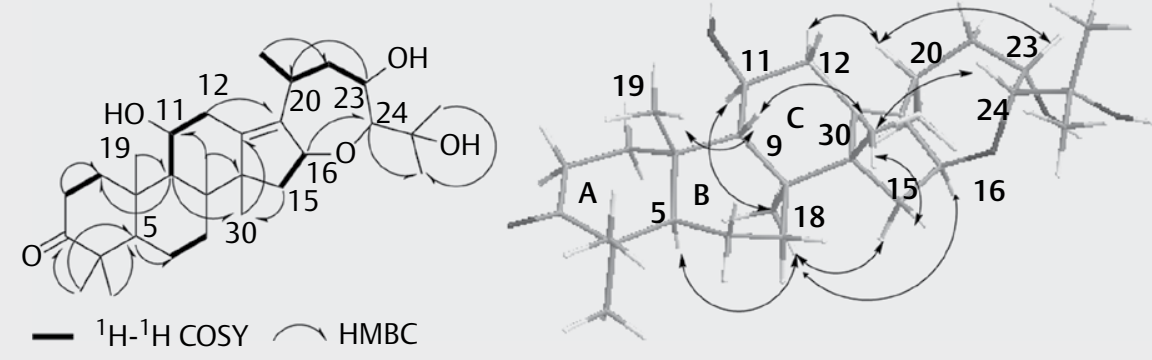

> Fig. 2 Key ${ }^{1} \mathrm{H}-{ }^{1} \mathrm{H}$ COSY, $\mathrm{HMBC}(\mathrm{H} \rightarrow \mathrm{C})$ and $\operatorname{NOESY}(\leftrightarrow)$ correlations of compound $\mathbf{1}$.

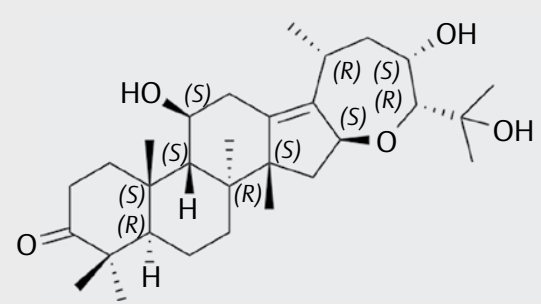

$1 a$

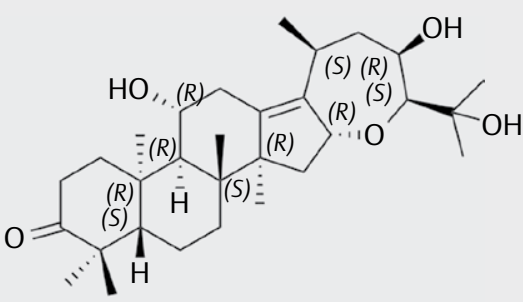

$1 b$

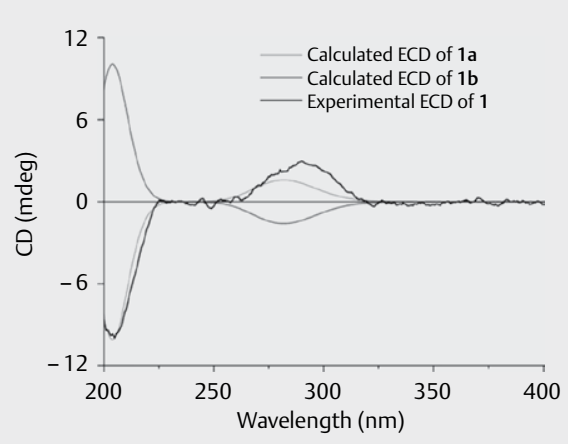

- Fig. 3 Experimental and calculated ECD spectra of 1 in $\mathrm{MeOH}$.
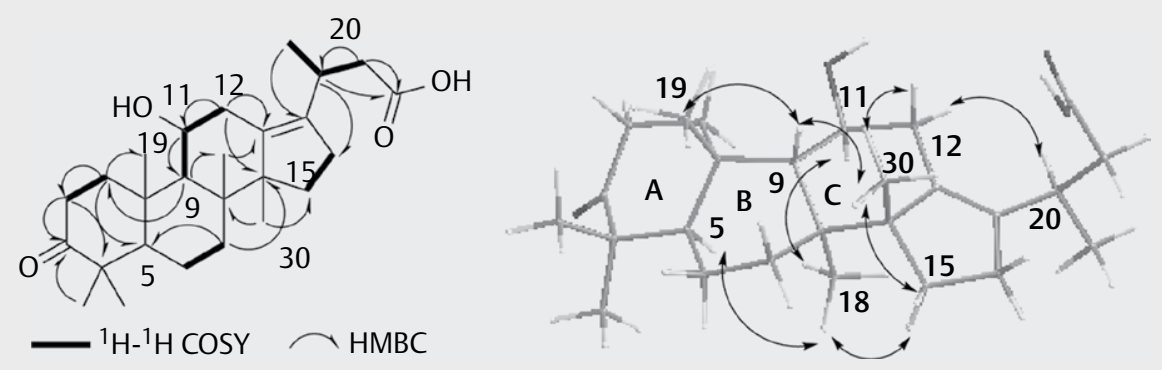

- Fig. 4 Key ${ }^{1} \mathrm{H}-{ }^{1} \mathrm{H}$ COSY, $\mathrm{HMBC}(\mathrm{H} \rightarrow \mathrm{C})$ and $\operatorname{NOESY}(\leftrightarrow)$ correlations of compound $\mathbf{2}$.

$311 \mathrm{G} *$ level) and the experimental data showed good agreement with $5 R, 8 R, 9 S, 10 S, 11 S$, and $14 S$, while the alternative form revealed a curve with the opposite cotton effect ( $\triangleright$ Fig. 5 ). Besides, the absolute configuration at $\mathrm{C}-20$ was considered to be $R$ based on the biogenesis of the protostane skeleton [22]. For the first time, the absolute configuration of $\mathbf{2}$ was discussed. Compound $\mathbf{2}$ was assigned as a new natural nortriterpenoid noralisolic acid $A$.

Lee reported the synthesis of noralisolic acid $A$, and its structure was assigned based on IR analysis and limited NMR data [23]. The ${ }^{13} \mathrm{C}-\mathrm{NMR}$ data of synthetic noralisolic acid A closely resembled those of compound 2, except for the lower field shift of the signal of C-22 ( $\left.\delta_{C} 57.7\right)$. However, this assignment of C-22's chemical shift was considered incorrect based on the following evidence: (1) the methylene carbon attached to the carboxyl group may give a signal at approximately $\delta_{\mathrm{C}} 38.0$ [24]; (2) an HMBC correlation from $\mathrm{H}-22\left(\delta_{\mathrm{H}} 2.31\right)$ to $\mathrm{C}-23\left(\delta_{\mathrm{C}} 177.0\right)$ permitted the carboxyl group of compound 2 to be attached to $\mathrm{C}-22$.

Compounds 1-15 were evaluated for their NF-kB inhibition activity in TNF- $\alpha$ stimulated HEK 293 cell line. Triterpenoids 8-10 and 14 showed moderate inhibitory activity with $\mathrm{IC}_{50}$ values of 64.7 , $32.3,47.3$, and $37.3 \mu \mathrm{M}$, respectively. However, the other compounds displayed mild NF-KB inhibition at a maximum tested concentration of $50 \mu \mathrm{M}$. Additionally, the $\mathrm{IC}_{50}$ of IMD-0354 was $13.3 \mu \mathrm{M}$, which was proved that the test system and calculation method were feasible. The results were shown in $>$ Table 2 and

Fig. 6. The results indicated that the $\mathrm{sp}^{3}$ hybrid C-16 of Alisma 


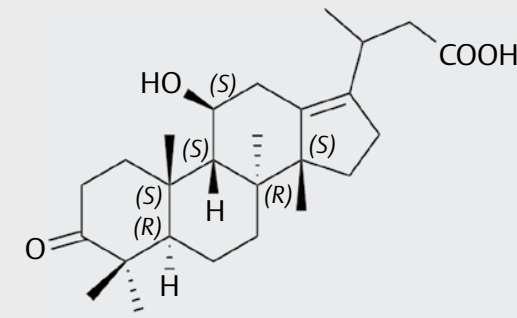

$2 a$

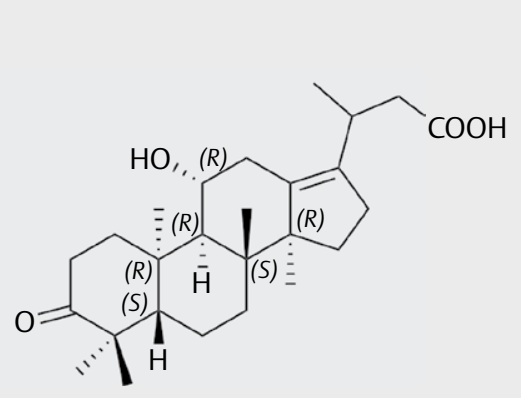

$2 b$

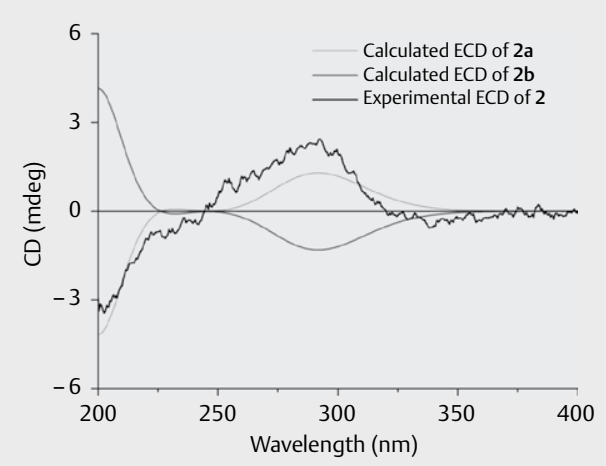

- Fig. 5 Experimental and calculated ECD spectra of compound 2 in $\mathrm{MeOH}$.

- Table 2 NF-KB cell line HEK293 inhibitory activities of active compounds.

\begin{tabular}{|c|c|c|}
\hline compound & inhibition rate (\%) & $\mathrm{IC}_{50}(\mu \mathrm{M})$ \\
\hline 8 & $58.4 \pm 0.0^{a}$ & 64.7 (C.I. 33.4-139.2) \\
\hline 9 & $94.8 \pm 0.4^{a}$ & 47.3 (C.I. 29.2-78.3) \\
\hline 10 & $51.7 \pm 3.7^{a}$ & 47.3 (C.I. 29.2-78.3) \\
\hline 14 & $64.8 \pm 3.8^{a}$ & 37.3 (C.I. 24.3-59.5) \\
\hline IMD0354 & $57.6 \pm 2.7^{b}$ & 13.3 (C.I. 10.2-17.6) \\
\hline \multicolumn{3}{|c|}{$\begin{array}{l}\text { a Measured in } 50 \mu \mathrm{M} ;{ }^{b} \text { Measured in } 30 \mu \mathrm{M} \text {. IC } \mathrm{C}_{50} \text { was afforded with } \\
\text { confidence interval }(n=2) \text {; C.I.: } 95 \% \text { confidence interval. Positive } \\
\text { control: IMD- } 0354 \text {. }\end{array}$} \\
\hline
\end{tabular}

triterpenoids (8-10 vs.3, 11, 13, and 15) is essential for NF-KB inhibition. The side-chain cyclization at C-17 depleted the NF-kB inhibition (9 vs.5). The hydroxyl groups at C-23 and the less hydrophilic groups at C-24/25 (-OAc or epoxy group) contributed to the NF-kB inhibitory activity ( 9 and 14 vs.3, 4, 6, 8, 10, 13, and 15) ( Fig. 7).

It has been reported that ethanol extract of $A$. orientale tuber could suppress LPS-induced NF-KB activity and NF-kB dependent gene expression in RAW 264.7 cells. Alisol B (9) was detected in EEAO by HPLC analysis but was not tested for its NF-KB inhibitory activity [13]. Our results confirmed that not only alisol B (9) but also 25-O-methylalisol A (8), 25-O-ethylalisol A (10), and alisol A 24-acetate (14) were involved in NF-kB activity. Compounds 9 and 14 were also reported to show anti-inflammatory and anti-allergic activities via inhibiting CD147 and MMP-9 secretion and leukotriene production [25-27].

In addition, compounds 1-15 were also tested for their antihuman dihydroorotate dehydrogenase activity by the reported method [28]. Nonetheless, they did not show any benefit (Data not shown).

\section{Materials and Methods}

\section{General experimental procedures}

IR spectra were recorded on Chiral IR-2X vibrational circular dichroism spectrometer in deuterated chloroform. The optical rotation was determined on JASCO P-2000 automatic polarimeter in $\mathrm{MeOH}$. NMR spectra were measured on Bruker Avance DRX-400. HRESIMS was performed on Waters Xevo G2-XS Q-TOF mass spectrometer, and the semi-preparative HPLC was performed on Chuangxin Tongheng $3050 \mathrm{~N}$ HPLC system with a $\mathrm{C}_{18}$ column (YMC-Pack ODS-A, $5 \mu \mathrm{m}, 10.0 \times 250 \mathrm{~mm})$. The ECD spectra were acquired in $\mathrm{MeOH}$ using JASCO J-815 circular dichroism spectrometer. Chemiluminescence measurements for the NF-KB cell line HEK293 inhibition assay were recorded on Envision (PerkinElmer).

\section{Solvents and chemicals}

IMD-0354 (purity $\geq 99 \%$ ) was purchased from Aladdin. DMEM was acquired from BI and FBS from Gibco. Penicillin and streptomycin $(\mathrm{P} / \mathrm{S})$ were obtained from Procell. Bright-Glo was gifted by Promega. TNF- $\alpha$ was purchased from Peprotech. DMSO was acquired from Sigma. The solvents used for extraction and chromatographic separation were of analytical purity.

\section{Plant material}

The rhizomes of $A$. orientale were sampled from Pengshan County, Sichuan Province in China, in November 2018 and authenticated by Prof. Tong Wu from Pharmacognosy Department. A voucher specimen (20190409) was deposited in the Shanghai Institute of Pharmaceutical Industry.

\section{Extraction and isolation}

The air-dried and powdered rhizomes $(5.0 \mathrm{~kg})$ of $A$. orientale were extracted with $60 \% \mathrm{EtOH}(15 \mathrm{~L} \times 3)$ for 3 times ( 2 h each time) under reflux. The combined solution was concentrated to crudeness in vacuo, and the crude extract was suspended in water $(3 \mathrm{~L})$, sequentially partitioning it with petroleum ether $\left(60-90^{\circ} \mathrm{C}\right)$ and dichloromethane $(3 \times 3 \mathrm{~L}$ each), respectively. The dichloromethane extract $(120.4 \mathrm{~g})$ was chromatographed on a silica gel column (CC) (6×72 cm; 200-300 mesh) and eluted by petroleum ether/ethyl acetate $(50: 1,20: 1,10: 1,4: 1,2: 1,1: 1, \mathrm{v} / \mathrm{v})$ to give 8 fractions (Fr.18 ) based on TLC analyses. Fr.4 (11.17 g) was subjected to an ODS-A gel CC $(6.6 \times 20 \mathrm{~cm} ; \mathrm{S}-50 \mu \mathrm{m}, 12 \mathrm{~nm}$; YMC $)$ and eluted by $\mathrm{MeOH} /$ $\mathrm{H}_{2} \mathrm{O}(1: 9,3: 7,1: 1,7: 3,9: 1$, and $1: 0 \mathrm{v} / \mathrm{v})$ to yield 9 fractions (Fr.4a4i). Fr.4b (1.73g) was purified using semi-preparative HPLC (60\% $\mathrm{CH}_{3} \mathrm{CN}$ in water; $4.0 \mathrm{~mL} / \mathrm{min}$; UV detection at $\lambda 210 \mathrm{~nm}$ ) to isolate 

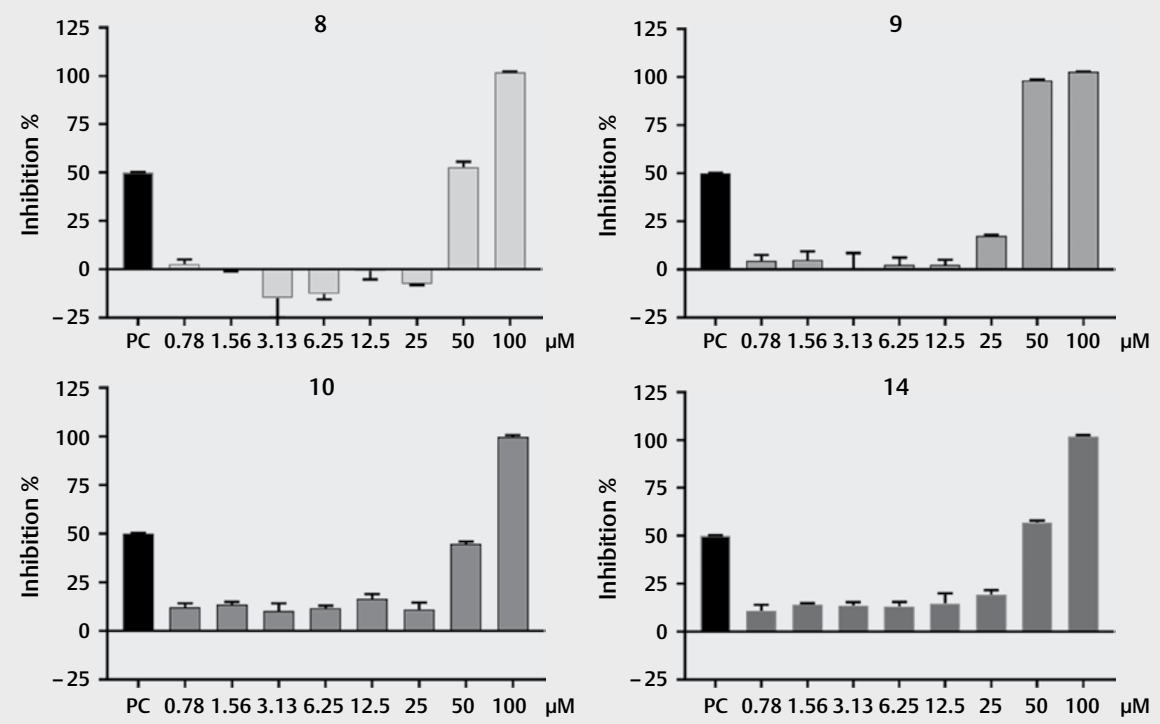

- Fig. 6 Inhibitory activity of compounds 8, 9, 10, and $\mathbf{1 4}$ in TNF- $\alpha$ stimulated HEK293 cells. HEK293 cells were treated with indicated doses of constituents for $24 \mathrm{~h}$, and then chemiluminescence was determined. IMD-0354 was used as a positive control and possessed an inhibitory rate of approximately $50 \%$ at $15 \mu \mathrm{M}$. Experiments were performed in duplicate, and data were represented as means \pm SD.

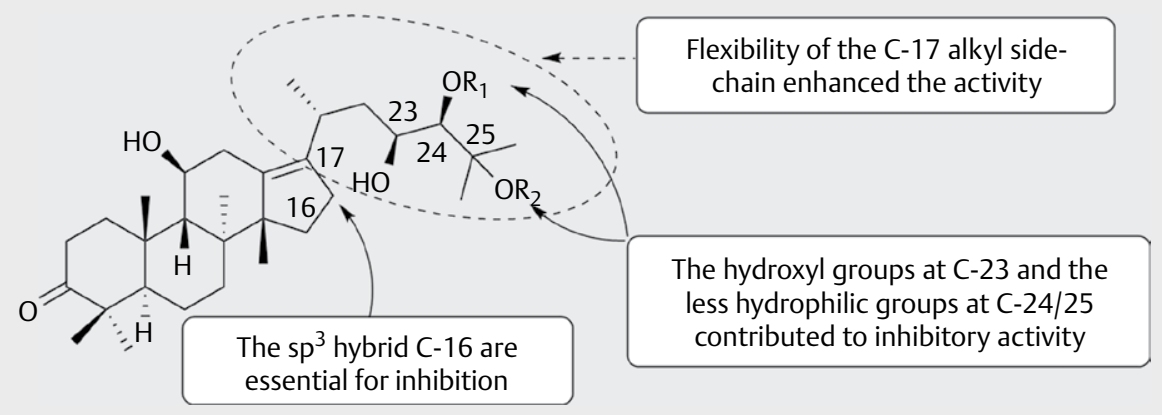

- Fig. 7 Protostane-type triterpenoids' structure-activity relationships.

compound 3 ( $\left.326.0 \mathrm{mg}, \mathrm{t}_{\mathrm{R}}=21 \mathrm{~min}\right)$. Fr. $4 \mathrm{~d}(0.79 \mathrm{~g})$ was purified via semi-preparative HPLC $\left(50 \% \mathrm{CH}_{3} \mathrm{CN}\right.$ in water; $4.0 \mathrm{~mL} / \mathrm{min}$; UV detection at $\lambda 210 \mathrm{~nm})$ to afford compounds $4\left(16.5 \mathrm{mg}, \mathrm{t}_{\mathrm{R}}=37 \mathrm{~min}\right)$ and 5 (10.2 mg, $\left.t_{R}=42 \mathrm{~min}\right)$. Compounds 6 (62.4 mg, $\left.t_{R}=65.2 \mathrm{~min}\right)$ and $2\left(22.9 \mathrm{mg}, \mathrm{t}_{\mathrm{R}}=27.9 \mathrm{~min} ; 97 \%\right.$ purity by HPLC) were obtained from Fr.4 $\mathrm{f}(0.44 \mathrm{~g})$ through semi-preparative HPLC eluted using $\mathrm{CH}_{3} \mathrm{CN} / \mathrm{H}_{2} \mathrm{O}(78: 22, \mathrm{v} / \mathrm{v} ; 3.0 \mathrm{~mL} / \mathrm{min}$; UV detection at $\lambda 210 \mathrm{~nm})$. Fr.4 h (2.96g) was subjected to semi-preparative HPLC with $\mathrm{CH}_{3} \mathrm{CN} /$ $\mathrm{H}_{2} \mathrm{O}$ (60:40-80:20, v/v, $90 \mathrm{~min} ; 4.0 \mathrm{~mL} / \mathrm{min}$; UV detection at $\lambda$ $210 \mathrm{~nm})$ to obtain compounds 7-10 $(62.5,85.8,228.5$, and $34.5 \mathrm{mg}$, respectively; $t_{R}=14.7,28.2,31.6$, and $41.2 \mathrm{~min}$ ). Compound $16\left(17.3 \mathrm{mg}, \mathrm{t}_{\mathrm{R}}=21.3 \mathrm{~min}\right)$ was purified from Fr. $4 \mathrm{i}(0.32 \mathrm{~g})$ by semi-preparative HPLC $\left(80 \% \mathrm{CH}_{3} \mathrm{CN}\right.$ in water; $4.0 \mathrm{~mL} / \mathrm{min}$; UV detection at $\lambda 210 \mathrm{~nm})$. Fr.6 (6.45 g) was subjected to an ODS-A gel $\mathrm{CC}$ eluted with $\mathrm{MeOH} / \mathrm{H}_{2} \mathrm{O}(1: 9,3: 7,1: 1,7: 3,9: 1$, and 1:0, v/v) to obtain 6 fractions (Fr.6a-6f). Fr.6b (1.17g) was further purified via semi-preparative HPLC $\left(40 \% \mathrm{CH}_{3} \mathrm{CN}\right.$ in water; $3.0 \mathrm{~mL} / \mathrm{min}$; UV de- tection at $\lambda 210 \mathrm{~nm})$ to obtain compounds $11,12,13(150.0,30.0$, and $26.0 \mathrm{mg}, \mathrm{t}_{\mathrm{R}}=24,56$ and $\left.31 \mathrm{~min}\right)$ and $1\left(16.1 \mathrm{mg}, \mathrm{t}_{\mathrm{R}}=33 \mathrm{~min}\right.$; $93 \%$ purity by HPLC). Compound $\mathbf{1 4}\left(12.1 \mathrm{mg}, \mathrm{t}_{R}=29 \mathrm{~min}\right)$ was obtained from Fr.6d $(0.37 \mathrm{~g})$ and purified using semi-preparative HPLC eluted with $\mathrm{CH}_{3} \mathrm{CN} / \mathrm{H}_{2} \mathrm{O}$ (57:43, v/v; $3.0 \mathrm{~mL} / \mathrm{min}$; UV detection at $\lambda 210 \mathrm{~nm})$. Finally, Fr.6e $(0.25 \mathrm{~g})$ was subjected to semi-preparative HPLC with $\mathrm{CH}_{3} \mathrm{CN} / \mathrm{H}_{2} \mathrm{O}(35: 65, \mathrm{v} / \mathrm{v} ; 3.0 \mathrm{~mL} / \mathrm{min}$; UV detection at $\lambda$ $210 \mathrm{~nm}$ ) to obtain compound $15\left(40.1 \mathrm{mg}, \mathrm{t}_{\mathrm{R}}=21.1 \mathrm{~min}\right)$.

Alismaketone $\mathbf{B}(\mathbf{1})$ : yellow amorphous powder; $[\alpha]_{D}^{24}+53.4$ (c 0.02, MeOH); $\mathrm{ECD}(\mathrm{MeOH}) \lambda_{\max }(\Delta \varepsilon) 290$ (+2.98), 205 ( - 9.96); IR $\left(\mathrm{CDCl}_{3}\right) \mathrm{V}_{\max } 3390,2941,1695 \mathrm{~cm}^{-1} ;{ }^{1} \mathrm{H}$ and ${ }^{13} \mathrm{C}$ NMR spectroscopic data (see > Tables 1); HRESIMS at $\mathrm{m} / \mathrm{z} 533.3499$ [M + HCOO] ${ }^{-}$ (calcd. for $\mathrm{C}_{31} \mathrm{H}_{49} \mathrm{O}_{7}, 533.3478$ ).

Noralisolic acid A (2): yellow amorphous powder; $[\alpha]_{D}^{24}+57.0$ (c 0.04, MeOH); ECD (MeOH) $\lambda_{\max }(\Delta \varepsilon) 293(+2.44), 203(-3.43)$; IR $\left(\mathrm{CDCl}_{3}\right) \mathrm{V}_{\max } 3444,2941,1747,1699,1654 \mathrm{~cm}^{-1} ;{ }^{1} \mathrm{H}$ and ${ }^{13} \mathrm{C}$ NMR spectroscopic data (see > Tables 1); HRESIMS at m/z 415.2817 
$[\mathrm{M}-\mathrm{H}]^{-}, 831.5751[2 \mathrm{M}-\mathrm{H}]^{-}, 461.2883$ [M + HCOO $^{-}$(calcd. for $\left.\mathrm{C}_{27} \mathrm{H}_{41} \mathrm{O}_{6}, 461.2903\right)$.

\section{ECD calculation}

Computational calculations were performed using the Gaussian 09 software. Conformers were generated by the MMFF94 force field and were obtained at $6 \mathrm{kcal} / \mathrm{mol}$. Conformational analyses and geometry optimizations were performed at the B3LYP/6-311 G * level in $\mathrm{MeOH}$. ECD calculations were performed by TDDFT at the B3LYP/6-311 G * level in MeOH. ECD spectra were obtained by weighing each geometric conformation's Boltzmann distribution rate with a bandwidth $\sigma$ of $0.3 \mathrm{eV}(\mathbf{1})$ or $0.4 \mathrm{eV}(\mathbf{2})$.

\section{Inhibitory effects on NF-KB cell line HEK293}

The NF-KB activity in the TNF- $\alpha$ stimulated HEK293 cell line was used to evaluate the inhibitory effects of all these isolates using the modified Bright-Glo method [29]. Compounds 1-15 were dissolved in DMSO to prepare a stock solution, and then each stock solution was serially diluted 2-fold to different concentrations using a culture medium. HEK293 cells were cultured in a DMEM medium plus $10 \% \mathrm{FBS}$ and $1 \% \mathrm{P} / \mathrm{S}$ were seeded in 96 -well plates at a density of 40,000 cells/well with $80 \mu \mathrm{L}$. After incubating at $37^{\circ} \mathrm{C}$ under $5 \%$ $\mathrm{CO}_{2}$ overnight, the tested compounds $(10 \mu \mathrm{L})$ were added to the wells. They were incubated at the same conditions for $2 \mathrm{~h}$, and TNF$\alpha(10 \mu \mathrm{L}, 20 \mathrm{ng} / \mathrm{mL})$ was then added to each well and incubated in the darkness for $24 \mathrm{~h}$. Chemiluminescence was measured on Envision after the addition of $50 \mu \mathrm{L}$ Bright-Glo Luciferase Assay Reagent to each well.

$$
\text { Inhibition }(\%)=100-(B / A \times 100)
$$

Where, B was the luminescence value of tested compounds, and A was luminescence of the negative control group (with cells, medium, DMSO, and TNF- $\alpha$ ).

Data were analyzed by GraphPad Prism v.7.0 and were presented as a geometric means with $95 \%$ confidence intervals of 2 independent experiments. IMD-0354 was used as a positive control and DMSO as a negative control.

\section{Supporting Information}

The 1D/2D NMR and HREIMS spectra of compounds $\mathbf{1}$ and $\mathbf{2}$, their optimized geometries, compounds 1 and 2's calculated conformers' ECD spectra, the triterpenoid's NF-kB cell line HEK293 inhibitory activities, as well as the compounds 3-16 experimental NMR data, are available as Supporting Information.

\section{Acknowledgments}

This work was supported by grants from the National Natural Science Foundation of China (No. 81603279), the National Science and Technology Project of China (No. 2018ZX09731-016), and the S\&T Program of Hebei (20272502D). The authors would like to thank Professor Li in the Institute of Materia Medica, Chinese Academy of Medical Sciences, and Peking Union Medical College, for her help in ECD calculation.
Conflicts of interest

The authors declare that they have no conflict of interest.

\section{References}

[1] Pharmacopoeia CoN. Pharmacopoeia of the People's Republic of China. Beijing: The Medicine Science and Technology Press of China; 2020

[2] Shu Z, Pu ], Chen L, Zhang Y, Rahman K, Qin L, Zheng C. Alisma orientale: Ethnopharmacology, phytochemistry and pharmacology of an important traditional Chinese medicine. Am J Chin Med 2016; 44: 227-251

[3] Zhang LL, Xu W, Xu YL, Chen X, Huang M, Lu JJ. Therapeutic potential of Rhizoma Alismatis: a review on ethnomedicinal application, phytochemistry, pharmacology, and toxicology. Ann N Y Acad Sci 2017; 1401: 90-101

[4] Li HM, Chen X], Luo D, Fan M, Zhang Z], Peng LY, Wu XD, Li RT, Ji X, Zhao Q-S. Protostane-type triterpenoids from Alisma orientale. Chem Biodivers 2017; 14: e1700452

[5] Xin XL, Xin XL, Zhao XY, Huo XK, Sun CP, Zhang HL, Tian Y, Zhao XY, Liu $Y$, Tian $X-G$, Wang $X$. Two new protostane-type triterpenoids from Alisma orientalis. Nat Prod Res 2018; 32: 189-194

[6] Li HM, Fan M, Xue Y, Peng LY, Wu XD, Liu D, Li RT, Zhao QS. Guaianetype sesquiterpenoids from Alismatis rhizoma and their anti-inflammatory activity. Chem Pharm Bull 2017; 65: 403-407

[7] Feng YL, Chen H, Tian T, Chen DQ, Zhao YY, Lin RC. Diuretic and anti-diuretic activities of the ethanol and aqueous extracts of Alismatis rhizoma. J Ethnopharmacol 2014; 154: 386-390

[8] Xu F, Yu H, Lu C, Chen J, Gu W. The cholesterol-lowering effect of alisol acetates based on HMG-CoA reductase and its molecular mechanism. Evid Based Complement Alternat Med 2016; 2016: 4753852

[9] Huo XK, Liu J, Yu ZL, Wang YF, Wang C, Tian XG, Ning J, Feng L, Sun CP, Zhang BJ, Ma XC. Alisma orientale extract exerts the reversing cholestasis effect by activation of farnesoid $X$ receptor. Phytomedicine 2018; 42: 34-42

[10] Lin HR. Triterpenes from Alisma orientalis act as farnesoid X receptor agonists. Bioorg Med Chem Lett 2012; 22: 4787-4792

[11] Zhao XY, Wang G, Wang Y, Tian XG, Zhao JC, Huo XK, Sun CP, Feng L, Ning J, Wang C, Zhang B-J, Wang X. Chemical constituents from Alisma plantago-aquatica subsp. orientale (Sam.) Sam and their anti-inflammatory and antioxidant activities. Nat Prod Res 2018; 32: 2749-2755

[12] Dou F, Miao H, Wang JW, Chen L, Wang M, Chen H, Wen AD, Zhao YY. An integrated lipidomics and phenotype study reveals protective effect and biochemical mechanism of traditionally used Alisma orientale juzepzuk in chronic kidney disease. Front Pharmacol 2018; 9: 53

[13] Han CW, Kwun M], Kim KH, Choi JY, Oh SR, Ahn KS, Lee JH, Joo M. Ethanol extract of Alismatis rhizoma reduces acute lung inflammation by suppressing NF-KB and activating Nrf2. J Ethnopharmacol 2013; 146: $402-410$

[14] Kim KH, Kwun M], Choi JY, Ahn KS, Oh SR, Lee YG, Christman JW, Sadikot RT, Han CW, Joo M. Therapeutic effect of the tuber of Alisma orientale on lipopolysaccharide-induced acute lung injury. Evid Based Complement Alternat Med 2013; 2013: 863892

[15] Jin H-G, Jin Q, Ryun Kim A, Choi H, Lee JH, Kim YS, Lee DG, Woo ER. A new triterpenoid from Alisma orientale and their antibacterial effect. Arch Pharmacal Res 2012; 35: 1919-1926

[16] Nakajima Y, Satoh Y, Katsumata M, Tsujiyama K, Ida Y, Shoji ]. Terpenoids of Alisma orientale rhizomes and the crude drug Alismatis rhizoma. Phytochemistry 1994; 36: 119-127 
[17] Yoshikawa M, Murakami T, Ikebata A, Ishikado A, Murakami N, Yamahara J, Matsuda $\mathrm{H}$. Absolute stereostructures of alismalactone 23-acetate and alismaketone-a 23-acetate, new seco-protostane and protostane-type triterpenes with vasorelaxant effects from Chinese Alismatis rhizoma. Chem Pharm Bull 1997; 45: 756-758

[18] Mai ZP, Wang C, Huo XK, Dong PP, Deng S, Zhang BJ, Zhang HL, Huang SS, Ma XC, Zhou K, Ge GB. Protostane triterpenoids from the rhizome of Alisma orientale exhibit inhibitory effects on human carboxylesterase 2. J Nat Prod 2015; 78: 2372-2380

[19] Hu XY, Guo YQ, Gao WY, Zhang T], Chen HX. Two new triterpenes from the rhizomes of Alisma orientalis. J Asian Nat Prod Res 2008; 10: 487-490

[20] Lainer ], Dawid C, Dunkel A, Gläser P, Wittl S, Hofmann T. Characterization of bitter-tasting oxylipins in poppy seeds (Papaver somniferum L.). J Agr and Food Chem 2020; 68: 10361-10373

[21] Matsuda H, Kageura T, Toguchida I, Murakami T, Kishi A, Yoshikawa M. Effects of sesquiterpenes and triterpenes from the rhizome of Alisma orientale on nitric oxide production in lipopolysaccharide-activated macrophages: absolute stereostructures of alismaketones-B 23-acetate and-C 23-acetate. Bioorg Med Chem Lett 1999; 9(21): 3081-3086

[22] Zhao M, Gödecke T, Gunn J, Anh Tuan L, Che C-T. Protostane and fusidane triterpenes: A mini-review. Molecules 2013; 18: 4054-4080

[23] Lee SM, Min BS, Bae KH. Chemical modification of alisol B 23-acetate and their cytotoxic activity. Arch Pharm Res 2002; 25: 608-612
[24] Ma Q, Han L, Bi X, Wang X, Mu Y, Guan P, Li L, Huang X. Structures and biological activities of the triterpenoids and sesquiterpenoids from Alisma orientale. Phytochemistry 2016; 131: 150-157

[25] Kubo M, Matsuda H, Tomohiro N, Yoshikawa M. Studies on Alismatis Rhizoma. I. Anti-allergic effects of methanol extract and six terpene components from Alismatis rhizoma (dried rhizome of Alisma orientale). Biol Pharm Bull 1997; 20: 511-516

[26] Lee JH, Kwon OS, Jin HG, Woo ER, Kim YS, Kim HP. The rhizomes of Alisma orientale and alisol derivatives inhibit allergic response and experimental atopic dermatitis. Biol Pharm Bull 2012; 35: 1581-1587

[27] Shi FF, Wei W, Wang YC, Su QP, Xue XH. The effect of alisol A 24-acetate on lipid metabolic factors ABCA1, CD36 and inflammatory factors CD147, MMP-9 in oxidized low density lipoprotein-induced macrophages. Chin J Arteriosclerosis 2016; 24: 7-12

[28] Yang Q, Jia A, Liu XZ, Han SY, Fan SY. Chemical constituents from Chloranthus elatior and their inhibitory effect onhuman dihydroorotate dehydrogenase. Planta Med advance online publication 2021; doi: 10.1055/a-1449-2642

[29] Hino K, Nagata H, Shimonishi M, Ido M. High-throughput screening for small-molecule adiponectin secretion modulators. J Biomol Screen 2011; 16: 628-636 